\title{
Anti-tick effect and cholinesterase inhibition caused by Prosopis juliflora alkaloids: in vitro and in silico studies
}

\author{
Efeito carrapaticida e inibição da acetilcolinesterase por alcaloides de \\ Prosopis juliflora: estudos in vitro e in silico

\begin{abstract}
Hélimar Gonçalves de Lima; Francianne Oliveira Santos';
Acidália Carine Vieira Santos ${ }^{1}$; Gisele Dias da Silva ${ }^{1}$; Rafaela Jesus dos Santos'; Thiago Campanharo Bahiense ${ }^{4}$; Samuel Silva da Rocha Pita ${ }^{3}$; Rosângela Soares Uzeda; Alexsandro Branco²; Silvia Lima Costa6; Maria José Moreira Batatinha'; Mariana Borges Botura2* (1)

${ }^{1}$ Laboratório de Toxicologia, Departamento de Anatomia, Patologia e Clínicas, Hospital de Medicina Veterinária, Universidade Federal da Bahia - UFBA, Salvador, BA, Brasil

${ }^{2}$ Departamento de Saúde, Universidade Estadual de Feira de Santana - UEFS, Feira de Santana, BA, Brasil

${ }^{3}$ Laboratório de Bioinformática e Modelagem Molecular - LaBiMM, Departamento do Medicamento, Faculdade de Farmácia, Universidade Federal da Bahia - UFBA, Salvador, BA, Brasil

${ }^{4}$ Departamento de Biointeração, Instituto de Ciências da Saúde, Universidade Federal da Bahia - UFBA, Salvador, BA, Brasil ${ }^{5}$ Departamento de Medicina Veterinária Preventiva e Produção Animal, Escola de Medicina Veterinária e Zootecnia, Universidade Federal da Bahia - UFBA, Salvador, BA, Brasil

${ }^{6}$ Departamento de Bioquímica e Biofísica, Instituto de Ciências da Saúde, Universidade Federal da Bahia - UFBA, Salvador, BA, Brasil
\end{abstract} \\ Kelli de Oliveira Carneiro ${ }^{2}$; Isabella Mary Alves Reis ${ }^{2}$; Isabela de Oliveira Estrela ${ }^{3}$; Humberto Fonseca de Freitas ${ }^{3}$;
}

How to cite: Lima HG, Santos FO, Santos ACV, Silva GD, Santos RJ, Carneiro KO, et al. Anti-tick effect and cholinesterase inhibition caused by Prosopis juliflora alkaloids: in vitro and in silico studies. Braz J Vet Parasito/ 2020; 29(2): e019819. https://doi.org/10.1590/ S1984-29612020036

\begin{abstract}
We investigated the in vitro acaricide activity of the methanolic extract (ME) and alkaloid-rich fraction (AF) of Prosopis juliflora on Rhipicephalus microplus and correlated this effect with acetylcholinesterase (AChE) inhibition. The acaricide activity was evaluated using adult and larval immersion tests. Also, we studied the possible interaction mechanism of the major alkaloids present in this fraction via molecular docking at the active site of $R$. microplus AChE1 (RmAChE1). Higher reproductive inhibitory activity of the AF was recorded, with effective concentration $\left(\mathrm{EC}_{50}\right)$ four times lower than that of the ME (31.6 versus $121 \mathrm{mg} / \mathrm{mL}$ ). The AF caused mortality of tick larvae, with lethal concentration $50 \%\left(\mathrm{LC}_{50}\right)$ of $13.8 \mathrm{mg} / \mathrm{mL}$. Both ME and AF were seen to have anticholinesterase activity on AChE of $R$. microplus larvae, while AF was more active with half-maximal inhibitory concentration (IC $\left.{ }_{50}\right)$ of $0.041 \mathrm{mg} / \mathrm{mL}$. The LC-MS/MS analyses on the AF led to identification of three alkaloids: prosopine (1), juliprosinine (2) and juliprosopine (3). The molecular docking studies revealed that these alkaloids had interactions at the active site of the RmAChE1, mainly relating to hydrogen bonds and cation-pi interactions. We concluded that the alkaloids of $P$. juliflora showed acaricide activity on $R$. microplus and acted through an anticholinesterase mechanism.
\end{abstract}

Keywords: Fabaceae, alkaloids, acaricide, anticholinesterase, molecular docking.

\section{Resumo}

A atividade carrapaticida in vitro do extrato metanólico (EM) e da fração de alcaloides (FA) de Prosopis juliflora foi investigada, frente ao Rhipicephalus microplus, e relacionada com a inibição da enzima acetilcolinesterase (AChE). A predição in silico das interações de alcaloides dessa fração com a AChE1 de R. microplus (RmAChE1) foi realizada por acoplamento molecular. A atividade carrapaticida foi avaliada, utilizando-se os ensaios de imersão de adultos e larvas. Maior efeito sobre parâmetros reprodutivos de teleóginas foi verificado para a FA, com valor de Concentração Efetiva $50 \%\left(\mathrm{CE}_{50}\right)(31.6 \mathrm{mg} / \mathrm{mL})$, quatro vezes menor do que o valor do $\mathrm{EM}(121 \mathrm{mg} / \mathrm{mL})$. A FA induziu mortalidade de larvas (Concentração Letal de $50 \%-\mathrm{CL}_{50}=13,8 \mathrm{mg} / \mathrm{mL}$ ). A inibição da atividade da $\mathrm{AChE}$ de larvas do carrapato foi observada para EM e FA, sendo a FA mais ativa (Concentração Inibitória $50 \%$ - $\mathrm{Cl}_{50}$ de $0,041 \mathrm{mg} / \mathrm{mL}$ ). As análises químicas da FA permitiram a identificação dos alcaloides prosopina (1), juliprosinina (2) e juliprosopina

Received October 25, 2019. Accepted April 30, 2020.

*Corresponding author: Mariana Borges Botura. E-mail: mbbotura@uefs.br 
(3). No ensaio in silico, observou-se que esses alcaloides podem interagir com o sítio ativo da RmAChE1, principalmente por ligações de hidrogênio e interações cátion-pi. Os alcaloides de $P$. juliflora têm atividade carrapaticida contra R. microplus, atuando através do mecanismo anticolinesterásico.

Palavras-chave: Fabaceae, alcaloides, carrapaticida, anticolinesterase, acoplamento molecular.

\section{Introduction}

Parasitic diseases impair livestock health and can cause high mortality rate in cattle herds if parasitism rates are high. Rhipicephalus microplus is a constant threat to cattle because of the direct and indirect damage that it causes to animal health, thereby leading to diminished reproductive efficiency and milk and meat production (Hue et al., 2015). It is a hematophagous parasite that transmits diseases by acting as a vector for pathogens such as Babesia bovis and Anaplasma marginale (Adenubi et al., 2016). Use of synthetic acaricides is the most common strategy for tick control; however, increasing resistance to these acaricides has encouraged a search for new bioactive molecules from plants, as treatment alternatives (Rosado-Aguilar et al., 2017).

Prosopis juliflora, popularly known as "algaroba" and "algarobeira", is a shrub belonging to the Fabaceae family that is native to arid and semi-arid regions. This species was introduced into northeastern Brazil more than 50 years ago and is used as a food source for humans and animals because of its high production of pods and the high palatability and nutritional value of the pods (Pegado et al., 2006). Several types of biological activity have been reported for this plant, such as anthelmintic (Lima et al., 2017), insecticidal (Dhivya et al., 2018) and antibacterial (Odhiambo et al., 2015). These effects have been attributed to the alkaloids that are present in this species. The alkaloids of greatest pharmacological importance are juliprosopine and juliprosine (Silva et al., 2013).

The in vitro anticholinesterase activity of juliprosopine upon electric eels (Electrophorus electricus) acetylcholinesterase enzyme (AChE) was described by Choudhary et al. (2005). AChE is an essential enzyme in the nervous system of ticks and is the main target for organophosphate and carbamate pesticides (Zhou \& Xia, 2009).

Because of the scarcity of information on the acaricide activity of $P$. juliflora, the aim of the present study was to evaluate the in vitro activity of the methanolic extract (ME) and alkaloid-rich fraction (AF) of this plant on the reproductive parameters of Rhipicephalus microplus, and to correlate this effect with inhibition of the AChE. Furthermore, in silico assays were performed to characterize the 3D structure of this tick's AChE1 and to predict the possible interaction mode of the major alkaloids of the AF at the active site of the AChE1.

\section{Materials and Methods}

\section{Plant material}

Pods from P. juliflora were collected in the municipality of Senhor do Bonfim, state of Bahia, Brazil, in September 2013. A voucher specimen was deposited at the Botanic Laboratory of Dr. Antônio Nonato Marques, Empresa Baiana de Desenvolvimento Agrícola S.A. (EBDA), Salvador, Bahia (number 5465).

\section{Obtainment of the methanol extract and alkaloid-rich fraction}

Air-dried and powdered pods (22.6 kg) from $P$. juliflora were macerated with 9 liters $(L)$ of $n$-hexane for two days. After filtration, the solvent was evaporated under reduced pressure and the remaining plant material was subsequently extracted with methanol $(\mathrm{MeOH})(9 \mathrm{~L})$, using the same procedure. The yield of methanol extract (ME) was $0.19 \%$. The ME was concentrated and dried under reduced pressure using a vacuum rotary evaporator (Buchi Rotavapour R-200, Switzerland), which was used to furnish the alkaloid-rich fraction (AF). This was obtained by means of acidic/basic modified extraction as described by Ott-Longoni et al. (1980). The yield of AF was $0.043 \%$.

\section{LC-MS/MS analysis on the alkaloid-rich fraction}

Liquid chromatography-tandem mass spectrometry (LC-MS/MS) was performed, coupled with an Esquire $3000^{\text {plus }}$ ion-trap mass spectrometer (Bruker Daltonics, Bremen, Germany) that was equipped with a CBM-20A controller, LC-20AD pump, SIL-20AC auto-sampler and SPD-20A detector, with an HPLC system connected to this. Separations were performed in a Phenomenex Luna C-18 column $(250 \times 4.6 \mathrm{~mm})$, with $5-\mu \mathrm{m}$ particle size. The elution gradient was run using a binary solvent system consisting of water containing $0.05 \%$ phosphoric acid (solvent $A$ ) and methanol 
(solvent B) at a constant flow rate of $1.0 \mathrm{~mL} / \mathrm{min}$. The gradient was as follows: 0 min, 0\% B; $25 \mathrm{~min}, 100 \% \mathrm{~B} ; 35 \mathrm{~min}$, $100 \%$ B; $36 \mathrm{~min}, 20 \% \mathrm{~B} ; 45 \mathrm{~min}, 20 \% \mathrm{~B}$. The injection volume was $20 \mu \mathrm{L}$. Data were acquired using a UV detector at $280 \mathrm{~nm}$ and $360 \mathrm{~nm}$. The capillary temperature was maintained at $300^{\circ} \mathrm{C}$ and the electrospray capillary voltage at $4.5 \mathrm{kV}$. The LC/MS was performed in positive ionization mode and with the full scan (m/z 100-1,500).

In vitro studies

\section{Rhipicephalus microplus samples}

R. microplus from POA strain (Porto Alegre strain) that is sensitive to acaricides currently on the market, and which were free of pathogens such as Babesia spp. and Anaplasma spp., was obtained from the Laboratório de Imunologia Aplicada à Sanidade Animal, Centro de Biotecnologia, Universidade Federal do Rio Grande do Sul (UFRGS). This colony has been maintained experimentally through feeding on Hereford calves (Bos taurus taurus) since 1976. Calves were purchased from an area that is naturally tick-free (Santa Vitória do Palmar, RS, Brazil; 33³2'2" S, 53²0'59" W) and were maintained in an isolated stall at the Federal Rural University of Rio Grande do Sul (UFRGS), Brazil, to avoid infestation by other ticks. These calves were handled in accordance with the institutional guidelines, as approved by the local ethics committee for animal use (Ethics Committee for Animal Experimentation of the Universidade Federal do Rio Grande do Sul).

Engorged females were carefully collected from the cattle, placed in Petri dishes with enough aeration and transported to the Laboratory of Toxicology, School of Veterinary Medicine and Animal Sciences, Federal University of Bahia, Salvador, BA, Brazil. These parasites were selected according to their integrity and motility. Following this, they were washed in distilled water, dried on absorbent paper and separated into two groups. In the first group, engorged females were used to evaluate the acaricidal activity up to $24 \mathrm{~h}$ after collection. In the second group, the females were incubated for two weeks $\left(26 \pm 2{ }^{\circ} \mathrm{C}\right.$ and relative humidity $\left.>80 \%\right)$, to yield larvae that were used to assess the anticholinesterase activity.

\section{Adult Immersion Test (AIT)}

The adult immersion test was conducted as described by Drummond et al. (1973). The ticks were weighed and separated into homogeneous groups with 10 females each, according to their weight (1.5 to $2 \mathrm{~g}$ ). The engorged females were immersed for $5 \mathrm{~min}$ in $5 \mathrm{~mL}$ of the following treatments: $\mathrm{ME}(91,127.6,178.6,250$ and $350 \mathrm{mg} / \mathrm{mL})$ and $\operatorname{AF}(16.9,33.2,65.1,127.6$ and $250 \mathrm{mg} / \mathrm{mL}$ ) from P. juliflora; negative control (ethanol 70\%); and positive control (Diazinon, $2.5 \mathrm{mg} / \mathrm{mL}$ ), diluted as recommended by the manufacturer (Agener União Saúde Animal ${ }^{\circledR}$ ). Following the immersion, these ticks were dried on absorbent paper, placed in Petri dishes and incubated for 15 days $\left(26 \pm 2{ }^{\circ} \mathrm{C}\right.$ and relative humidity $>80 \%$ ), in order to evaluate oviposition. After this period, the eggs were weighed, transferred to glass tubes and incubated under the same conditions as described above. After 21 days, the larval hatching percentage was estimated visually using a stereomicroscope. Four repetitions were used for each of the treatments.

The data obtained were recorded and used to calculate the following parameters:

Egg production index $($ EPI $)=($ weight of eggs/weight of engorged females $(g)) \times 100($ Bennett, 1974);

Reproductive efficiency index $(\mathbf{R E I})=$ (egg-mass weight $(\mathrm{g}) /$ weight of engorged females $(\mathrm{g})$ ) $\times$ \% egg hatching x 20,000 (Drummond et al., 1973);

Efficacy of product $(E P)=[($ REI negative control group - REl treated group $) /$ REl negative control group $] \times 100$ (Drummond et al., 1973).

\section{Larval Immersion Test (LIT)}

The LIT was used to evaluate the effect of the AF of $P$. juliflora, most active fraction in AIT, against $R$. microplus larvae (Silva et al., 2009), at concentrations of 4.2 to $65.1 \mathrm{mg} / \mathrm{mL}$. Approximately 100 larvae of 14 to 21 days of age were used, obtained through oviposition from untreated engorged female ticks and collected from naturally infested cattle (Catu, state of Bahia, Brazil). The larvae were put into 5-mL syringes, which were cut next to the needle. The syringe was closed using a fine-weft fabric fixed with an orthodontic rubber band, and the larvae were immersed in the treatments for five minutes and maintained at $27 \pm 1^{\circ} \mathrm{C}$ and $80 \pm 5 \%$ relative humidity. An orifice of approximately $0.1 \mathrm{~mm}$ in diameter was made in the middle of the syringe. This procedure was repeated for 
each concentration of the $\mathrm{AF}$, and for the positive control (Fipronil, $10 \mathrm{mg} / \mathrm{mL}$ - diluted as recommended by the manufacturer) and negative control (70\% ethanol). Larval mortality was recorded after $24 \mathrm{~h}$. Only larvae that had the ability to walk were considered alive. All treatments were set up as three replicates for each concentration tested. Living and dead larvae were counted, and the percentage mortality was calculated as:

$$
\% \text { mortality }=(\text { number of dead larvae/total number of larvae }) \times 100
$$

\section{In vitro anticholinesterase activity of larvae from $R$. microplus}

The anticholinesterase activity of the ME and AF was determined spectrophotometrically, in accordance with the methodology described by Ellman et al. (1961), as modified by Wright \& Ahrens (1988). Samples of R. microplus larvae $(100 \mathrm{mg})$ were macerated in deionized water $(3 \mathrm{~mL})$ and were centrifuged at 1,000 $\times \mathrm{g}$ for 5 min. Then, the supernatants were used as the enzyme source. In a microtube, $50 \mu \mathrm{L}$ of $\mathrm{ME}$ (final concentration: $0.26,0.64$, $1.6,4$ and $10 \mathrm{mg} / \mathrm{mL}$ ) and AF (final concentration: $0.001,0.005,0.025,0.125$ and $0.625 \mathrm{mg} / \mathrm{mL}$ ) of $P$. juliflora, the negative control (70\% ethanol) and positive control (Eserine/Sigma-aldrich ${ }^{\circledast}$; final concentration: $0.014 \mathrm{mg} / \mathrm{mL}$ ) were preincubated with AChE solution $(200 \mu \mathrm{L})$ during $20 \mathrm{~min}$. at $4{ }^{\circ} \mathrm{C}$. For determination of AChE activity, phosphate buffer solution with $\mathrm{pH} 8.0(0.1 \mathrm{M}, 2,8 \mathrm{~mL})$ and enzyme solution $(200 \mu \mathrm{L})$ were homogenized and incubated at $35^{\circ} \mathrm{C}$ for $2 \mathrm{~min}$. Then, 5,5'-dithiobis (2-nitrobenzoic acid) (DTNB $10 \mathrm{mM}, 200 \mu \mathrm{L}$ ) and acetylthiocholine iodide $(7.5 \mathrm{mM}, 25 \mu \mathrm{L})$ were added to initiate the reaction. The absorbance was measured on the spectrophotometer (UV-Vis SP-220 Spectrophotometer, Biospectro, Japan) at $412 \mathrm{~nm}$ (0 and $6 \mathrm{~min})$. Each sample was assayed with nine replicates. AChE percentage inhibition was calculated by using the equation:

Inhibition $(\%)=[1-($ reaction rate sample/reaction rate negative control $)] \times 100$

\section{In silico studies}

\section{Comparative modeling of AChE1 from R. microplus (RmAChE1)}

The amino acid sequence of the cholinergic domain (residues 51 to 528) of RmAChE1 (access code: A0A0F2P2D6), which is available on the UniProt server (UniProt, 2019), was aligned with the primary sequences from the crystallographic structure of the human AChE (HsAChE; PDB ID: 4EY7) and the Torpedo californica AChE (PDB ID: 2WFZ), using the Clustal Omega server (EMBL-EBI, 2019a). Both the human and the Torpedo californica AChE are available from the Protein Data Bank (RCSB PDB, 2019). From the alignment, 100 models of the RmAChE1 were built using the Modeler 9.18 software (Šali \& Blundell, 1993). These were refined through four simulated annealing cycles (flags: autosched.slow; 500 interactions; refine.slow) and were classified according to the scoring function QMEAN6 (SIB, 2019) and the SSAgree values (Benkert et al., 2009). Next, the compatibility between the atomic model (3D) of the 10 best models, according to QMEAN score, and its own amino acid sequence (1D) was calculated using the Verify3D server (http://services.mbi.ucla.edu/Verify_3D/, Lüthy et al., 1992). An overall folding quality scale was used for each model. The stereochemistry quality was estimated using the Ramachandran plot (Ramachandran et al., 1963), which was calculated on the PDBsum server (EMBL-EBI, 2019b; Laskowski et al., 1997). The model with the best folding and stereochemistry parameters was used for the molecular docking assays.

\section{Preparation of the RmAChE1 receptor structures and alkaloids}

The 3D structure model of the RmAChE1 was prepared for docking assays using the Biopolymer module, which is available on the Syby ${ }^{\circledR}-X$ 2.1.1 platform (TRIPOS Associates, 2013). Firstly, hydrogen atoms were added and optimized to prioritize $\mathrm{H}$-bond interactions. Histidine, glutamate and aspartate residues were manually checked for orientation, protonation and tautomeric states. The protonation state of residues was determined using Propka 3.1 (Sondergaard et al., 2011; Rostkowski et al., 2011), with pH = 8.0. Following this, AMBER Force Field 99 charges (Wang et al., 2000) were assigned to the protein. The same protocol was performed for the human isoform (HsAChE; 4EY7).

Major alkaloid structures from the AF (Figures 1 and 2), as well as donepezil, were sketched on the Marvin ${ }^{\circledR}$ Sketch 16.8.29 software (Marvin Sketch 16.8.29, 2017, ChemAxon, 2019) and were later converted into the 3D 


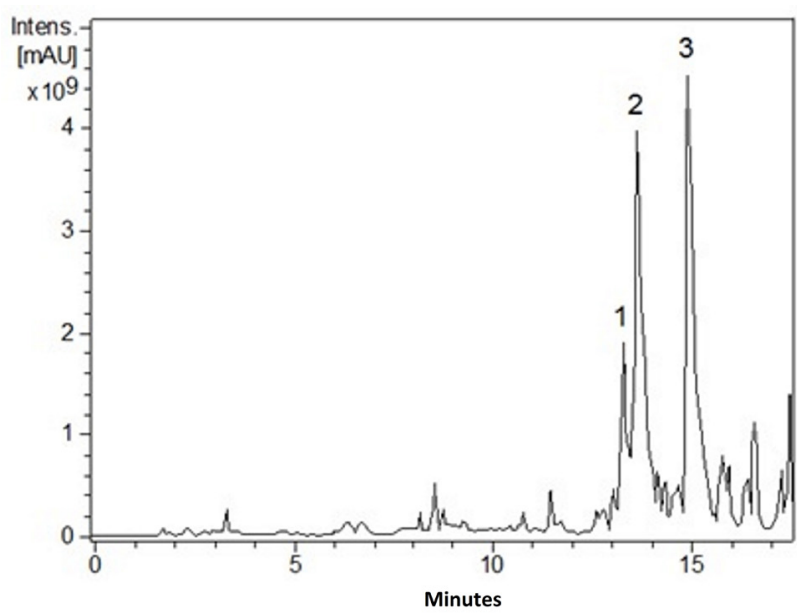

Figure 1. LC-MS/MS chromatogram (positive mode) of the AF of Prosopis juliflora (algaroba). Prosopine (1), juliprosinine (2) and juliprosopine (3). Units are in milli Absorbance Units (mAU).
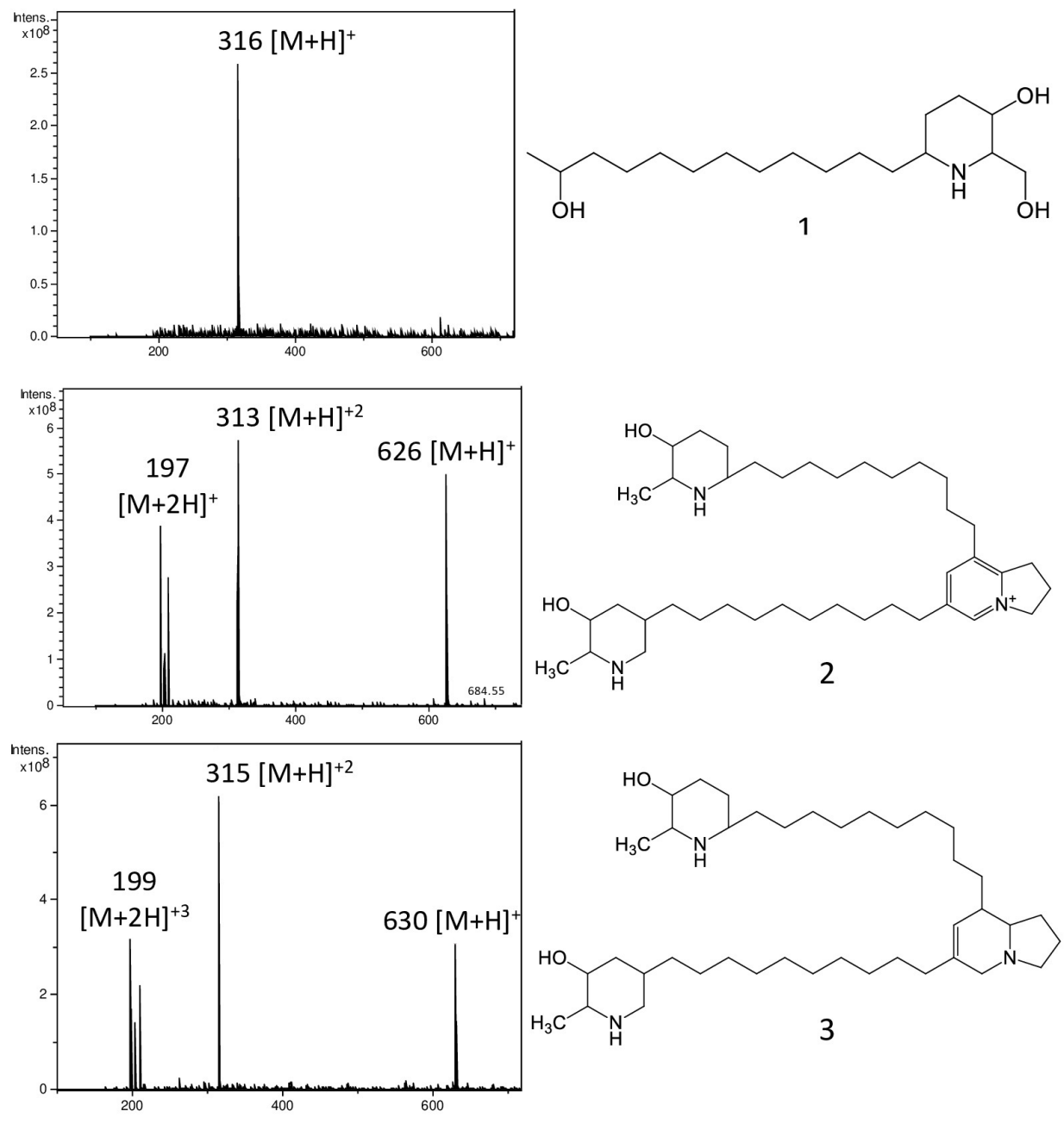

Figure 2. LC-MS/MS spectrum and chemical structures: prosopine (1), juliprosinine (2) and juliprosopine (3).

format using the Concord module (standard parameters), which is available on Syby ${ }^{\circledR}-X$ 2.1.1 (TRIPOS Associates, 2013). Afterwards, atomic Gasteiger-Huckel charges (Gasteiger \& Marsili, 1980; Hou et al., 2013) were added and the structures were energy-minimized using the conjugate gradient method until the convergence criteria $(0.001 \mathrm{kcal} / \mathrm{mol}$ or maximum number of interactions $=50,000)$ were reached at the water dielectric constant $(\varepsilon=80.4)$, in the Tripos force-field (Clark et al., 1989). 


\section{Molecular docking studies on piperidine alkaloids}

Piperidine alkaloid (ligand) docking was carried out in the GOLD suite v. 5.5 (CCDC, Cambridge, UK). The search space was defined unrestrictedly as a radius of $18 \AA$, centered on the oxygen (gamma) of the catalytic residue Serine 222. The protein residues remained rigid throughout the calculation, while the ligands were kept flexible (additional N-pyramidal and ring-corner movements were allowed).

Docking simulations were performed using the Lamarckian genetic algorithm (Morris et al., 1998), which is a hybrid of a genetic algorithm and a local search algorithm that is available through GOLD 5.5 (Greenblatt et al., 2007; Jones et al., 1995). The docking parameters were set to default, except for the following: trials of 100 LGA runs for each ligand, initial population size of 250 individuals, random starting position and conformation and $2.5 \times 10^{6}$ generations at a selective pressure of 1:1, undergoing mutation (95\%), crossover (95\%) and migration (10\%) in 10 islands and 5 niches. Each docking simulation produced 100 different docked conformations that were later ranked using the Piecewise Linear Potential function (ChemPLP), which was implemented in the GOLD suite (Greenblatt et al., 2007; Jones et al., 1995). Next, the complexes of RmAChE-alkaloids were visually analyzed using the Pymol 1.3 software (The PyMOL Molecular Graphics System, Version 2.0 Schrödinger, LLC). This procedure was also performed for the donepezil structure, in relation to HsAChE.

\section{Statistical analysis}

The results obtained from the biological assays were expressed as the mean \pm standard deviation (SD). The normality of data was assessed using the Shapiro-Wilk test. The acaricidal evaluation and anticholinesterase activity also underwent univariate analysis of variance (ANOVA) followed by post-hoc Tukey's honest significant test (Tukey's HSD test, 5\%), using the GraphPad Prism statistical software (version 5.0).

\section{Results}

\section{Chemical analysis}

The LC-MS/MS chromatogram of the AF in the positive mode is shown in Figure 1. Figure 2 presents the MS spectra and the alkaloid structures characterized in this fraction. Alkaloid $1\left(\mathrm{~T}_{\mathrm{R}} .13 .4 \mathrm{~min}\right)$ exhibited a protonated molecular ion at $\mathrm{m} / \mathrm{z} 316.27[\mathrm{M}+\mathrm{H}]^{+}$, which fitted the molecular formula $\mathrm{C}_{18} \mathrm{H}_{37} \mathrm{O}_{3} \mathrm{~N}$. The MS/MS fragmentation pattern obtained from this alkaloid showed fragment ions at $\mathrm{m} / \mathrm{z} 298.32[\mathrm{M}-18+\mathrm{H}]^{+}$and $280.33[\mathrm{M}-36+\mathrm{H}]^{+}$, which were formed by the loss of one and two molecules of water, respectively. Thus, alkaloid 1 was assigned to a prosopine. Alkaloids 2 ( $\left.T_{R^{*}} .13 .7 \mathrm{~min}\right)$ and $\mathbf{3}\left(\mathrm{T}_{\mathrm{R}} \cdot 15.0 \mathrm{~min}\right.$ ) showed protonated molecular ions at $\mathrm{m} / \mathrm{z} 626.54[\mathrm{M}+\mathrm{H}]^{+}$and $630.62[\mathrm{M}+\mathrm{H}]^{+}$, which were identified as juliprosinine $\left(\mathrm{C}_{40} \mathrm{H}_{72} \mathrm{~N}_{3} \mathrm{O}_{2}\right)$ and juliprosopine $\left(\mathrm{C}_{40} \mathrm{H}_{76} \mathrm{~N}_{3} \mathrm{O}_{2}\right)$, respectively.

\section{Adult immersion test}

Table 1 showed the effect of the ME and AF of $P$. juliflora on the reproductive parameters of adult females of R. microplus. The ME and AF induced significant reductions $(p<0.05)$ in the oviposition and hatching rates of the ticks, in a concentration-dependent manner. The efficacy of the AF ( 65.1 to $250 \mathrm{mg} / \mathrm{mL})$ and $\mathrm{ME}(350 \mathrm{mg} / \mathrm{mL})$ did not differ from that of the positive control (Diazinon; $2.5 \mathrm{mg} / \mathrm{mL})(\mathrm{p}>0.05)$. The $\mathrm{EC}_{50}$ values were 31.6 and $121 \mathrm{mg} / \mathrm{mL}$ for the AF and ME, respectively.

\section{Larval immersion test}

Table 2 presents the effect of the AF against the $R$. microplus larvae. The AF had larvicidal activity against R. microplus, with $\mathrm{LC}_{50}$ value of $13.8 \mathrm{mg} / \mathrm{mL}$. The $A F$, at the highest concentration tested $(65.1 \mathrm{mg} / \mathrm{mL})$, showed a percentage of larvae mortality of $90 \%$.

\section{In vitro anticholinesterase activity against larvae of $R$. microplus}

At the highest concentration $(0.625 \mathrm{mg} / \mathrm{mL})$, the AF inhibited AChE activity in $95 \%$ and did not differ from the positive control (eserine, $0.014 \mathrm{mg} / \mathrm{mL})(p>0.05)$. The $I C_{50}$ of the $A F$ was $0.041 \mathrm{mg} / \mathrm{mL}$. For the $\mathrm{ME}(10 \mathrm{mg} / \mathrm{mL})$, the maximum percentage enzyme inhibition was $52 \%$ (Table 3 ). 
Table 1. Percentage oviposition, hatching and efficacy (mean \pm standard deviation) among adult females of Rhipicephalus microplus, exposed to the immersion test with the methanolic extract (ME) and alkaloid-rich fraction (AF) of Prosopis juliflora. Different letters in columns indicate statistically significant difference (one-way ANOVA followed by the Tukey's HSD test, p <0.05).

\begin{tabular}{|c|c|c|c|c|c|}
\hline Treatments & $\begin{array}{l}\text { Concentration } \\
(\mathrm{mg} / \mathrm{mL})\end{array}$ & $\begin{array}{c}\text { Egg production } \\
(\%)\end{array}$ & $\begin{array}{l}\text { Hatching } \\
\text { (\%) }\end{array}$ & $\begin{array}{l}\text { Efficacy } \\
(\%)\end{array}$ & $E C_{50}$ \\
\hline \multirow{5}{*}{ ME } & 91 & $29^{e} \pm 4.2$ & $93^{\mathrm{bf}} \pm 2.9$ & $24^{b} \pm 15.7$ & \\
\hline & 127.6 & $25^{d} \pm 3.5$ & $70^{\text {ad }} \pm 16.8$ & $54^{c} \pm 11.4$ & \\
\hline & 178.6 & $16^{c} \pm 4.7$ & $72^{\mathrm{af}} \pm 13.0$ & $70^{\text {cf }} \pm 7.1$ & $121 \mathrm{mg} / \mathrm{mL}$ \\
\hline & 250 & $3^{b} \pm 0.3$ & $53^{\text {ad }} \pm 37.9$ & $88^{d} \pm 9.2$ & $R^{2}: 0.94$ \\
\hline & 350 & $9^{\mathrm{a}} \pm 7.1$ & $45^{\mathrm{ad}} \pm 32.2$ & $97^{d} \pm 4.2$ & \\
\hline \multirow{5}{*}{$A F$} & 16.9 & $41^{f} \pm 3.8$ & $42^{\mathrm{de}} \pm 7.6$ & $45^{e} \pm 4.7$ & \\
\hline & 33.2 & $10^{\mathrm{a}} \pm 0.4$ & $23^{\mathrm{ce}} \pm 3.5$ & $73^{f} \pm 4.6$ & \\
\hline & 65.1 & $2^{b} \pm 3.5$ & $3^{c} \pm 5.9$ & $96^{d} \pm 7.3$ & $31.6 \mathrm{mg} / \mathrm{mL}$ \\
\hline & 127.6 & $2^{b} \pm 3.2$ & $0^{c} \pm 0.0$ & $99^{d} \pm 2.7$ & $R^{2}: 0.94$ \\
\hline & 250 & $0^{b} \pm 0.0$ & $0^{c} \pm 0.0$ & $100^{d} \pm 0.0$ & \\
\hline $\mathrm{EtOH} 70 \%$ & - & $48^{g} \pm 2.8$ & $95^{b} \pm 4.4$ & $0.0^{\mathrm{a}} \pm 0.0$ & - \\
\hline Diazinon & 2.5 & $0.0^{\mathrm{b}} \pm 0.0$ & $8^{c} \pm 15.0$ & $98^{d} \pm 2.1$ & - \\
\hline
\end{tabular}

Table 2. Percentage mortality among Rhipicephalus microplus larvae exposed to the alkaloid-rich fraction (AF) of $P$. juliflora, positive control (fipronil, $10 \mathrm{mg} / \mathrm{mL}$ ) and negative control (ethanol 70\%). Different letters in columns indicate statistically significant difference (one-way ANOVA followed by the Tukey's HSD test, $\mathrm{p}<0.05$ ).

\begin{tabular}{cccc}
\hline Treatments & Concentration $(\mathrm{mg} / \mathrm{mL})$ & Mortality (\%) & LC $_{\mathbf{5 0}}$ \\
\hline & 4.2 & $24^{\mathrm{b}} \pm 1.4$ & $13.8 \mathrm{mg} / \mathrm{mL}$ \\
$\mathrm{R}^{2}: 0,92$ \\
AF & 8.5 & $25^{\mathrm{b}} \pm 2.8$ & $50^{\mathrm{c}} \pm 6.9$ \\
& 16.9 & $64^{\mathrm{d}} \pm 6.1$ & - \\
EtOH 70\% & 33.2 & $90^{\mathrm{e}} \pm 1.3$ & - \\
Fipronil & 65.1 & $0^{\mathrm{a}} \pm 0$ & - \\
\hline
\end{tabular}

Table 3. Percentage inhibition (mean \pm standard deviation) of in vitro AChE activity of larvae of $R$. microplus exposed to the methanolic extract (ME) and alkaloid-rich fraction (AF) of $P$. juliflora. Positive control: eserine $(0.014 \mathrm{mg} / \mathrm{mL})$; negative control: ethanol $70 \%$. Different letters in columns indicate statistically significant difference (one-way ANOVA followed by the Tukey's HSD test, $p<0.05$ ).

\begin{tabular}{|c|c|c|c|}
\hline Treatments & $\begin{array}{l}\text { Concentration } \\
(\mathrm{mg} / \mathrm{mL})\end{array}$ & Inhibition AChE activity (\%) & $I C_{50}$ \\
\hline & 0.26 & $19^{c} \pm 1.5$ & \\
\hline & 0.64 & $31^{d} \pm 3.1$ & \\
\hline \multirow[t]{5}{*}{ ME } & 1.6 & $39^{\mathrm{e}} \pm 4.2$ & - \\
\hline & 4 & $46^{f} \pm 2.7$ & \\
\hline & 10 & $52^{g} \pm 1.6$ & \\
\hline & 0.001 & $6^{\mathrm{ab}} \pm 1.4$ & \\
\hline & 0.005 & $13^{b} \pm 2.6$ & \\
\hline \multirow[t]{3}{*}{$\mathrm{AF}$} & 0.025 & $38^{\text {de }} \pm 5.5$ & $0.041 \mathrm{mg} / \mathrm{mL}$ \\
\hline & 0.125 & $79^{h} \pm 5.4$ & $R^{2}: 0.99$ \\
\hline & 0.625 & $95^{i} \pm 0.7$ & \\
\hline EtOH $70 \%$ & - & $2^{\mathrm{a}} \pm 0.5$ & - \\
\hline Eserine & 0.014 & $100^{i} \pm 0.0$ & - \\
\hline
\end{tabular}




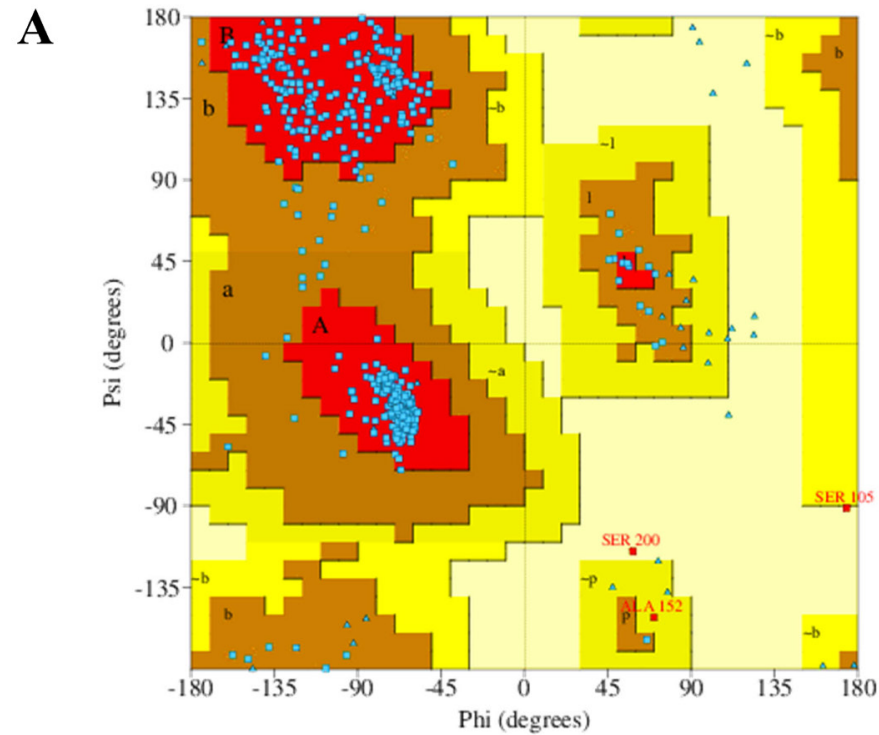

B

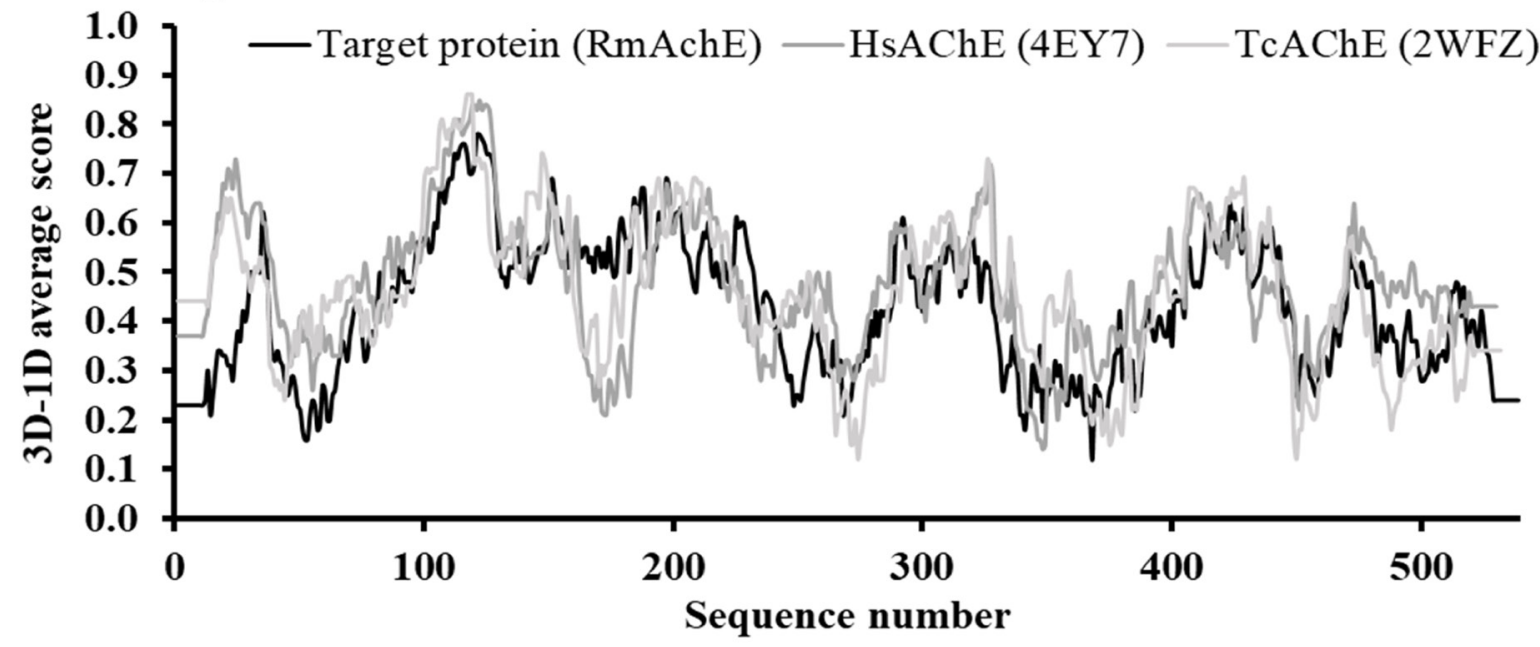

Figure 3. Stereochemical evaluation of the RmAChE1 model. (A) Ramachandran plot: favorable regions (red); additionally allowed (orange); generously permitted (yellow) and not allowed (white); (B) verify-3D plot for averaged 3D-1D values for RmAChE (better model) and HsAChE (template, PDB ID: 4EY7) and TcAChE (template, PDB ID: 2WFZ). Values higher than 0.2 show compatibility between protein folding (3D) and sequences (1D).

In silico studies

\section{Comparative modeling of RmAChE1}

100 models of RmAChE1 were built using the Modeler 9.18 software (Šali \& Blundell, 1993), from high-resolution crystallography templates: human AChE (HsAChE, PDB ID: 4EY7) and Torpedo californica (TcAChE, PDB ID: 2WFZ). Alignment between the template primary sequence and the target (RmAChE1) showed moderate sequential identity (> 42\%) (Figure A.1 - Supplementary Material'), which enabled proper use of the Modeler software (Webb \& Sali, 2016; Šali \& Blundell, 1993). After generation of RmAChE1 models, the quality evaluation was performed. The RmAChE1 best-ranked model showed that $98.8 \%$ of the residues were in the "allowed region" (Figure $3 \mathrm{~A}$ ) and that $98.7 \%$ of the residues presented correct folding (Figure 3B). Hence, it showed stereochemical characteristics,

\footnotetext{
Methanolic extract (ME), alkaloid-rich fraction (AF), acetylcholinesterase (AChE), adult immersion test (AIT), effective concentration $50 \%\left(\mathrm{EC}_{50}\right)$, liquid chromatography-tandem mass spectrometry (LC-MS/MS), egg production index (EPI), reproductive efficiency index (REI), efficacy of product (EP), acetylthiocholine iodide (ATChI), phosphate buffer (PBS), protein data bank (PDB), human AChE (HsAChE), Torpedo californica AChE (TcAChE), Rhipicephalus microplus AChE (RmAChE), peripherical anionic site (PAS). Note: Supplementary data associated with this article.
} 
(Figure B.1 - Supplementary Material) and folding that were compatible with the experimental model proteins (PDB ID templates: 4EY7 and 2WFZ). This therefore makes it possible to use this model in future docking studies.

\section{Molecular docking assays on piperidine alkaloids}

Docking studies usually require previous steps to evaluate the parameters that are to be used in the search (Cole et al., 2005; Jain, 2008). Briefly, a ligand co-crystallized with a protein is redocked with its receptor. Thus, the deviation values (root mean square deviation, RMSD) of the best ligand posed in relation to co-crystallized coordinates ought to be less than $2 \AA$ (depending on the ligand size). Based on this hypothesis, donepezil was redocked to the receptor HsAChE (PDB ID: 4EY7) (Figure C.1 - Supplementary Material) and the best-ranked pose showed an interaction profile similar to that observed for the co-crystallized structure (RMSD $=1.97 \AA$ ). The parameters used for the docking are enough for generation of reliable binding positions with HsAChE and these parameters were applied for RmAChE1 docking studies. Following this, docking of three alkaloids (juliprosinine, juliprosopine and prosopine) was performed at RmAChE1 (Figure 4).

Our docking experiments showed that the 2-methyl-3-piperidinol of juliprosinine (2) perform hydrogen bonding interactions with serine 222, histidine 460 (catalytic site residues) (Figure 4A) and juliprosopine (3) (Figure 4B) hydrogen bonds with glycine 141, serine 222, serine 303 and glycine 305. Those of 2-(hydroxymethyl)-3-piperidinol of prosopine (Figure 4C) with the catalytic site residues (serine 222 and histidine 460) and peripherical anionic site (PAS; tyrosine 144) were also present, along with $\pi$-cation interaction with tryptophan 103 (anionic subsite). $\Pi$-cation interactions were also observed between the tyrosine 144 residue of the RmAChE1 and the 2,3-dihydro-1H-indolizine (Figure 4A) or hexahydroindolizine (Figure 4B) substructures. Additionally, hydrogen bonds with the PAS residues were assessed between the radical 2-methyl-3-piperidinol of juliprosinine (2) and the residues of serine 303 and glycine 305 and between the terminal hydroxyl of prosopine (1) and glutamate 300.

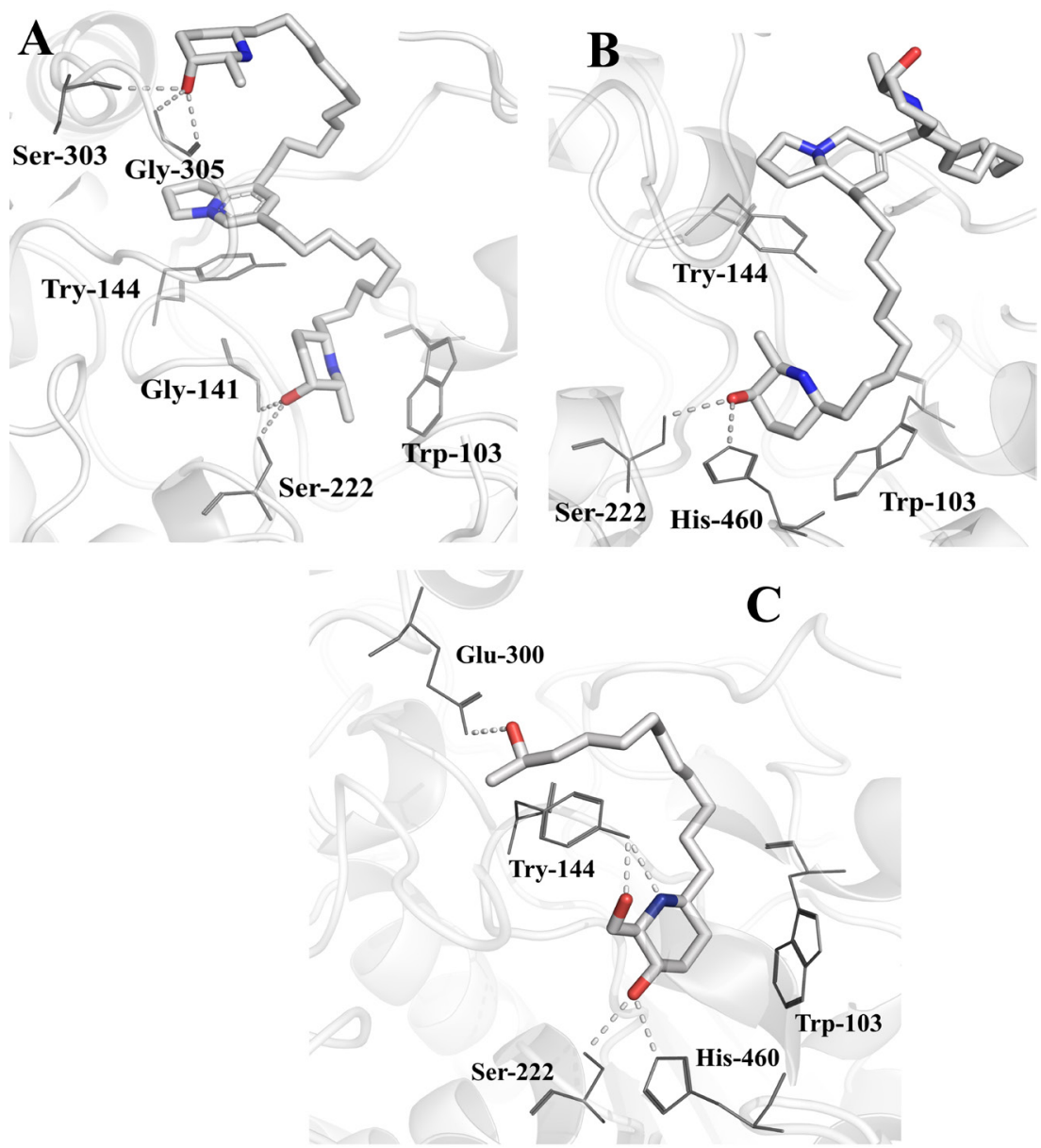

Figure 4. Main interactions between the RmAChE1 residues and piperidine alkaloids: (A) juliprosinine; (B) juliprosopine; and (C) prosopine. These images were generated using the Pymol 1.3 software (The PyMOL Molecular Graphics System, Version 2.0 Schrödinger, LLC). 


\section{Discussion}

In the present study, the ME and AF of $P$. juliflora were shown to have acaricidal activity against $R$. microplus. The AF was four times more effective on adult females of $R$. microplus than was the ME, thus suggesting that the alkaloids present in this plant are the compounds responsible for this activity. In addition, the AF was more active on larvae $\left(\mathrm{LC}_{50}=13.8 \mathrm{mg} / \mathrm{mL}\right)$ than on adult females $\left(\mathrm{EC}_{50}=31.6 \mathrm{mg} / \mathrm{mL}\right)$ of $R$. microplus. These differences may be related to the greater mass of individual engorged adults and thinner cuticle of $R$. microplus larvae, which would make these stages more sensitive than the adult females (Cruz et al., 2016; Conceição et al., 2017). The LC-MS/MS analyses on the AF led to identification of three alkaloids (prosopine, juliprosinine and juliprosopine). These compounds were characterized through comparisons with data in the literature (Ott-Longoni et al., 1980; Ahmad et al., 1989; Singh \& Swapnil, 2011; Singh \& Verma, 2012; Santos et al., 2013). Other types of antiparasitic activity exhibited by this plant, such as insecticidal (Yadav et al., 2015; Dhivya et al., 2018) and anthelmintic (Lima et al., 2017), have also been described.

These findings are the first scientific reports on the anti-tick activity of the alkaloids of $P$. juliflora. The activity of alkaloid and non-alkaloid fractions of Leucas indica against Rhipicephalus (Boophilus) annulatus was studied previously, and only the alkaloid fraction $(50 \mathrm{mg} / \mathrm{mL})$ induced adult tick mortality (66.67\%) and inhibition of fecundity (55.16\%) (Divya et al., 2014).

From our evaluation of the anticholinesterase effect, the inhibition of AChE activity produced by the ME and AF of $P$. juliflora makes it possible to include them in the group of potent inhibitors ( $>50 \%$ inhibition) of this enzyme, according to the classification of Vinutha et al. (2007). The AF was more active at a lower concentration $\left(I C_{50}=0.041 \mathrm{mg} / \mathrm{mL}\right)$ than the $\mathrm{ME}(10 \mathrm{mg} / \mathrm{mL} ; 52 \%)$, thus indicating that alkaloids are the bioactive compounds of $P$. juliflora responsible for the anticholinesterase activity. Previous studies reported that juliprosopine, isolated from P. juliflora, was active in vitro against the AChE of electric eels (Electrophorus electricus) (Choudhary et al., 2005).

Our work indicates that the alkaloids of $P$. juliflora have the same macromolecular target as do organophosphate and carbamate pesticides. According to Tan et al. (2011), inhibition of the AChE leads to increased levels of the neurotransmitter acetylcholine and to paralysis and death of the tick.

With the aim of understanding the interactions of these alkaloids (presented in the AF) with the AChE of R. microplus (RmAChE), in silico studies were performed on RmAChE1. The higher affinity with the substrate (acetylcholine; $\mathrm{ACh}$ ) and higher conversion rates of RmAChE2 and RmAChE3 that were previously observed (Temeyer et al., 2010) suggest that RmAChE1 is very important for tick survival. However, the lack of data on the crystallographic structure of RmAChE limits both the designing of new acaricidal compounds and knowledge of the mechanism of action of these molecules (Williams et al., 2005; Lionta et al., 2014; Ferreira et al., 2018). Thus, comparative modeling (homology modeling) plays a significant role in reducing these limitations because it enables investigation, at the atomic level, of the molecular interactions of anticholinesterase compounds through molecular docking (Schmidt et al., 2014).

Since these in vitro assays with these compounds do not allow assessment of the molecular inhibition mechanism against RmAChE, docking studies were conducted. These were based on previous results relating to the non-competitive inhibition mechanism of juliprosopine against the AChE of E. electricus (Choudhary et al., 2005). Docking assays for other two alkaloids were conducted in relation to RmAChE1 because high Tanimoto coefficients (Bajusz et al., 2015; Rogers \& Tanimoto, 1960) were achieved (juliprosinine T.C. > 95\% and prosopine T.C. $=45 \%$ ). This coefficient describes the percentage of structural similarity between two distinct compounds (Bajusz et al., 2015): the more similar their structures are, the higher the Tanimoto coefficient is.

The docking showed that the alkaloids seem to interact preferentially with the residues of the catalytic site, anionic subsite and PAS of RmAChE1 (Figure 4). Although the binding mode was distinct from that proposed before (Choudhary et al., 2005), the patterns of interactions were very similar (Figure 4). Our docking results corroborated what had been described for other known ligands of AChEs, such as tanshinone (Cheung et al., 2013), galantamine (Greenblatt et al., 2007), huperzine A and donepezil (Cheung et al., 2012). For instance, the residue tryptophan 286 (present in PAS of HsAChE) has an important $\pi-\pi$ stacking interaction with donepezil (PDB ID: 4EY7) and tanshinone (PDB ID: 4MOE). However, at RmAChE1, this residue was replaced by threonine (Thr 301), thus leading to the loss of this interaction (Figure 4 and A.1), which reduced the affinity of these compounds against the enzyme (Swale et al., 2013). The docking results suggest that this lack of interaction was compensated by the $\pi$-cation interaction between the 2,3-dihydro-1 $\mathrm{H}$-indolizine or hexahydroindolizine from alkaloids and tyrosine 144 from RmAChE1 (Figure 4). 
$\pi$-cation and $\pi-\pi$ interactions with tryptophan 86 (anionic site of the HsAChE) and hydrogen bonds with serine 203 also seem to be important for the mechanisms for inhibition caused by huperzine A (PDB ID: 4EY5), galantamine (PDB ID: 1DX6) and donepezil (PDB ID: 4EY7). These interactions were similar to our results between the 2-methyl-3-piperidinol and 2-(hydroxymethyl)-3-piperidinol groups and the tryptophan 103 and serine 222 residues of RmAChE1 (Figure 4).

\section{Conclusion}

The alkaloids of $P$. juliflora presented an in vitro acaricidal effect on the larvae and engorged females of R. microplus, and they inhibited acetylcholinesterase. An in silico assay on the main alkaloids obtained from the alkaloid-rich fraction (juliprosopine, juliprosinine and prosopine) suggested that these compounds preferentially interacted at the catalytic and PAS sites of RmAChE1. These interaction profiles are similar to those described for several known AChE inhibitors. To achieve a better description of this mechanism of action, additional in vitro studies on recombinant RmAChE1 and in silico molecular dynamic simulations are required.

\section{Acknowledgements}

The authors would like to thank the Coordenação de Aperfeiçoamento de Pessoal de Nível Superior (CAPES, Finance Code 001) and the Fundação de Amparo à Pesquisa do Estado da Bahia (FAPESB; S. S. R. P. grant numbers JCB-0039/2013 and RED-008/2013) for the financial support.

The authors would also like to thank Professor Itabajara da Silva Vaz Júnior, of the Universidade Federal do Rio Grande do Sul, Brazil, for kindly making available the POA strain used in this study, and to thank the teacher Abilio Borghi for the grammar review of the manuscript.

\section{References}

Adenubi OT, Fasina FO, McGaw LJ, Eloff JN, Naidoo V. Plant extracts to control ticks of veterinary and medical importance: A review. S AfrJ Bot 2016; 105: 178-193. http://dx.doi.org/10.1016/j.sajb.2016.03.010.

Ahmad VU, Sultana A, Qazi S. Alkaloids from the leaves of Prosopis juliflora. J Nat Prod 1989; 52(3): 497-501. http://dx.doi. org/10.1021/np50063a005.

Bajusz D, Rácz A, Héberger K. Why is Tanimoto index an appropriate choice for fingerprint-based similarity calculations? J Cheminform 2015; 7(1): 20. http://dx.doi.org/10.1186/s13321-015-0069-3. PMid:26052348.

Benkert P, Kunzli M, Schwede T. QMEAN server for protein model quality estimation. Nucleic Acids Res 2009;37(Suppl 2): W510-W514. http://dx.doi.org/10.1093/nar/gkp322. PMid:19429685.

Bennett GF. Oviposition of Boophilus microplus (Canestrini) (Acarida Ixodidae). I. Influence of tick size on egg production. Acarologia 1974; 16(1): 52-61. PMid:4463680.

ChemAxon [online]. 2019 [cited 2019 Oct 25]. Available from: http://www.chemaxon.com

Cheung J, Gary EN, Shiomi K, Rosenberry TL. Structures of human acetylcholinesterase bound to dihydrotanshinone I and territrem B show peripheral site flexibility. ACS Med Chem Lett 2013; 4(11): 1091-1096. http://dx.doi.org/10.1021/ml400304w. PMid:24900610.

Cheung J, Rudolph MJ, Burshteyn F, Cassidy MS, Gary EN, Love J, et al. Structures of human acetylcholinesterase in complex with pharmacologically important ligands. J Med Chem 2012; 55(22): 10282-10286. http://dx.doi.org/10.1021/jm300871x. PMid:23035744.

Choudhary MI, Nawaz SA, Zaheer-ul-Haq, Azim MK, Ghayur MN, Lodhi MA, et al. Juliflorine: a potent natural peripheral anionicsite-binding inhibitor of acetylcholinesterase with calcium-channel blocking potential, a leading candidate for Alzheimer's disease therapy. Biochem Biophys Res Commun 2005; 332(4): 1171-1177. http://dx.doi.org/10.1016/j.bbrc.2005.05.068. PMid:16021692.

Clark M, Cramer RD, Van Opdenbosch N. Validation of the general purpose tripos 5.2 force field. J Comput Chem 1989; 10(8): 982-1012. http://dx.doi.org/10.1002/jcc.540100804.

Cole JC, Murray CW, Nissink JW, Taylor RD, Taylor R. Comparing protein-ligand docking programs is difficult. Proteins 2005; 60(3): 325-332. http://dx.doi.org/10.1002/prot.20497. PMid:15937897.

Conceição RS, Carneiro MMAA, Reis IMA, Branco A, Vieira IJC, Braz-Filho R, et al. In vitro acaricide activity of Ocotea aciphylla (Nees) Mez. (Lauraceae) extracts and identification of the compounds from the active fractions. Ticks Tick Borne Dis 2017; 8(2): 275-282. http://dx.doi.org/10.1016/j.ttbdis.2016.11.013. PMid:27916582. 
Cruz PB, Barbosa AF, Zeringóta V, Melo D, Novato T, Fidelis QC, et al. Acaricidal activity of methanol extract of Acmella oleracea L. (Asteraceae) and spilanthol on Rhipicephalus microplus (Acari: Ixodidae) and Dermacentor nitens (Acari: Ixodidae). Vet Parasitol 2016; 228: 137-143. http://dx.doi.org/10.1016/j.vetpar.2016.08.026. PMid:27692316.

Dhivya K, Vengateswari G, Arunthirumeni M, Karthi S, Senthil-Nathan S, Shivakumar MS. Bioprospecting of Prosopis juliflora (Sw.) DC seed pod extract effect on antioxidant and immune system of Spodoptera litura (Lepidoptera: noctuidae). Physiol Mol Plant Pathol 2018; 101: 45-53. http://dx.doi.org/10.1016/j.pmpp.2017.09.003.

Divya TM, Soorya VC, Amithamol KK, Juliet S, Ravindran R, Nair SN, et al. Acaricidal activity of alkaloid fractions of Leucas indica Spreng against Rhipicephalus (Boophilus) annulatus tick. Trop Biomed 2014; 31(1): 46-53. PMid:24862044.

Drummond RO, Ernst SE, Trevino JL, Gladney WJ, Graham OH. Boophilus annulatus and B. microplus: laboratory tests of insecticides. J Econ Entomol 1973; 66(1): 130-133. http://dx.doi.org/10.1093/jee/66.1.130. PMid:4690254.

Ellman GL, Courtney KD, Andres V Jr, Featherstone RM. A new and rapid colorimetric determination of acetylcholinesterase activity. Biochem Pharmacol 1961; 7(2): 88-95. http://dx.doi.org/10.1016/0006-2952(61)90145-9. PMid:13726518.

EMBL-EBI [online]. 2019a [cited 2019 Oct 25]. Available from: www.ebi.ac.uk/Tools/msa/clustalo/

EMBL-EBI [online]. 2019b [cited 2019 Oct 25]. Available from: www.ebi.ac.uk/thornton-srv/databases/cgi-bin/pdbsum

Ferreira LG, Oliva G, Andricopulo AD. From medicinal chemistry to human health: current approaches to drug discovery for cancer and neglected tropical diseases. An Acad Bras Cienc 2018;90(1 Suppl 1): 645-661. http://dx.doi.org/10.1590/00013765201820170505 . PMid:29451603.

Gasteiger J, Marsili M. Iterative partial equalization of orbital electronegativity: a rapid access to atomic charges. Tetrahedron 1980; 36(22): 3219-3228. http://dx.doi.org/10.1016/0040-4020(80)80168-2.

Greenblatt HM, Kryger G, Lewis T, Silman I, Sussman JL. Diverse, high-quality test set for the validation of protein-ligand Docking Performance. J Med Chem 2007; 50(4): 726-741. http://dx.doi.org/10.1021/jm061277y. PMid:17300160.

Hou X, Du J, Zhang J, Du L, Fang H, Li M. How to improve docking accuracy of AutoDock4.2: a case study using different electrostatic potentials. J Chem Inf Model 2013; 53(1): 188-200. http://dx.doi.org/10.1021/ci300417y. PMid:23244516.

Hüe T, Cauquil L, Fokou JBH, Dongmo PMJ, Bakarnga-via I, Menut C. Acaricidal activity of five essential oils of Ocimum species on Rhipicephalus (Boophilus) microplus larvae. Parasitol Res 2015; 114(1): 91-99. http://dx.doi.org/10.1007/s00436-014-4164-6. PMid:25300420.

Jain AN. Bias, reporting, and sharing: computational evaluations of docking methods. J Comput Aided Mol Des 2008; 22(3-4): 201212. http://dx.doi.org/10.1007/s10822-007-9151-x. PMid:18075713.

Jones G, Willett P, Glen RC. Molecular recognition of receptor sites using a genetic algorithm with a description of desolvation. J Mol Biol 1995; 245(1): 43-53. http://dx.doi.org/10.1016/S0022-2836(95)80037-9. PMid:7823319.

Laskowski RA, Hutchinson EG, Michie AD, Wallace AC, Jones ML, Thornton JM. PDBsum: a web-based database of summaries and analyses of all PDB structures. Trends Biochem Sci 1997; 22(12): 488-490. http://dx.doi.org/10.1016/S0968-0004(97)01140-7. PMid:9433130.

Lima HG, Gomes DC, Santos NSS, Dias ER, Botura MB, Batatinha MJM, et al. Prosopis juliflora pods alkaloid-rich fraction: in vitro anthelmintic activity on goat gastrointestinal parasites and its cytotoxicity on Vero cells. Pharmacogn Mag 2017;13(51 Suppl 3): S684-S687. http://dx.doi.org/10.4103/pm.pm_3_17. PMid:29142433.

Lionta E, Spyrou G, Vassilatis DK, Cournia Z. Structure-based virtual screening for drug discovery: principles, applications and recent advances. Curr Top Med Chem 2014; 14(16): 1923-1938. http://dx.doi.org/10.2174/1568026614666140929124445. PMid:25262799.

Lüthy R, Bowie JU, Eisenberg D. Assessment of protein models with three-dimensional profiles. Nature 1992; 356(6364): 83-85. http://dx.doi.org/10.1038/356083a0. PMid:1538787.

Morris GM, Goodsell DS, Halliday RS, Huey R, Hart WE, Belew RK, et al. Automated docking using a lamarckian genetic algorithm and an empirical binding free energy function. J Comput Chem 1998; 19(14): 1639-1662. http://dx.doi.org/10.1002/(SICI)1096987X(19981115)19:14<1639::AID-JCC10>3.0.CO;2-B.

Odhiambo RS, Patrick KG, Helen KL, Gathu NC, Kimani NF, Waithaka WR, et al. Antibacterial activity of ethanolic extracts of Prosopis juliflora against gram negative bacteria. Eur J Exp Biol 2015; 5(110): 43-46.

Ott-Longoni R, Viswanathan N, Hesse M. . The structure of the alkaloid juliprosopine from Prosopis juliflora A. Dc. Helv Chim Acta 1980; 63(7): 2119-2129. http://dx.doi.org/10.1002/hlca.19800630738.

Pegado CMA, Andrade LA, Félix LP, Pereira IM. Efeitos da invasão biológica de algaroba - Prosopis juliflora (Sw.) DC. sobre a composição e a estrutura do estrato arbustivo-árboreo da caatinga no Município de Monteiro, PB, Brasil. Acta Bot Bras 2006; 20(4): 887-898. http://dx.doi.org/10.1590/S0102-33062006000400013. 
Ramachandran GN, Ramakrishnan C, Sasisekharan V. Stereochemistry of polypeptide chain configurations. J Mol Bio/ 1963; 7(1): 95-99. http://dx.doi.org/10.1016/S0022-2836(63)80023-6. PMid:13990617.

RCSB PDB [online]. 2019 [cited 2019 Oct 25]. Available from: www.rcsb.org

Rogers DJ, Tanimoto TT. A computer program for classifying plants. Science 1960; 132(3434): 1115-1118. http://dx.doi.org/10.1126/ science.132.3434.1115. PMid:17790723.

Rosado-Aguilar JA, Arjona-Cambranes K, Torres-Acosta JFJ, Rodríguez-Vivas RI, Bolio-González ME, Ortega-Pacheco A, et al. Plant products and secondary metabolites with acaricide activity against ticks. Vet Parasito/ 2017; 238: 66-76. http://dx.doi.org/10.1016/j. vetpar.2017.03.023. PMid:28385541.

Rostkowski M, Olsson MHM, Sondergaard CR, Jensen JH. Graphical analysis of pH-dependent properties of proteins predicted using PROPKA. BMC Struct Biol 2011; 11(1): 6. http://dx.doi.org/10.1186/1472-6807-11-6. PMid:21269479.

Šali A, Blundell TL. Comparative protein modelling by satisfaction of spatial restraints. J Mol Bio/ 1993; 234(3): 779-815. http:// dx.doi.org/10.1006/jmbi.1993.1626. PMid:8254673.

Santos ET, Pereira MLA, Silva CFPG, Souza-Neta LC, Geris R, Martins D, et al. Antibacterial activity of the alkaloid-enriched extract from Prosopis juliflora pods and its influence on in vitro ruminal digestion. Int J Mol Sci 2013; 14(4): 8496-8516. http://dx.doi. org/10.3390/ijms14048496. PMid:23595000.

Schmidt T, Bergner A, Schwede T. Modelling three-dimensional protein structures for applications in drug design. Drug Discov Today 2014; 19(7): 890-897. http://dx.doi.org/10.1016/j.drudis.2013.10.027. PMid:24216321.

Silva VDA, Pitanga BPS, Nascimento RP, Souza CS, Coelho PLC, Menezes-Filho N, et al. Juliprosopine and juliprosine from Prosopis juliflora leaves induce mitochondrial damage and cytoplasmic vacuolation on cocultured glial cells and neurons. Chem Res Toxicol 2013; 26(12): 1810-1820. http://dx.doi.org/10.1021/tx4001573. PMid:23923817.

Silva WC, Martins JRS, Souza HEM, Heinzen H, Cesio MV, Mato M, et al. Toxicity of Piper aduncum L. (Piperales: Piperaceae) from the Amazon forest for the cattle tick Rhipicephalus (Boophilus) microplus (Acari: Ixodidae). Vet Parasitol 2009; 164(2-4): 267-274. http://dx.doi.org/10.1016/j.vetpar.2009.06.006. PMid:19573994.

Singh S, Swapnil SKV. Antibacterial properties of alkaloid rich fractions obtained from various parts of Prosopis juliflora. Int J Pharm Sci Res 2011; 2(3): 114-120.

Singh S, Verma SK. Study of the distribution profile of piperidine alkaloids in various parts of Prosopis juliflora by the application of Direct Analysis in Real Time Mass Spectrometry (DART-MS). Nat Prod Bioprospect 2012; 2(5): 206-209. http://dx.doi.org/10.1007/ s13659-012-0069-1.

Sondergaard CR, Olsson MHM, Rostkowski M, Jensen JH. Improved treatment of ligands and coupling effects in empirical calculation and rationalization of pKa Values. J Chem Theory Comput 2011; 7(7): 2284-2295. http://dx.doi.org/10.1021/ct200133y. PMid:26606496.

Swale DR, Tong F, Temeyer KB, Li A, Lam PC, Totrov MM, et al. Inhibitor profile of bis(n)-tacrines and N-methylcarbamates on acetylcholinesterase from Rhipicephalus (Boophilus) microplus and Phlebotomus papatasi. Pestic Biochem Physiol 2013; 106(3): 85-92. http://dx.doi.org/10.1016/j.pestbp.2013.03.005. PMid:24187393.

Swiss Institute of Bioinformatics - SIB [online]. 2019 [cited 2019 Oct 25]. Available from: https://swissmodel.expasy.org/qmean

Tan F, Wang L, Wang J, Wu X, Zhu H, Jiang L, et al. Enhanced pesticide sensitivity of novel housefly acetylcholinesterases: a new tool for the detection of residual pesticide contamination. Bioprocess Biosyst Eng 2011; 34(3): 305-314. http://dx.doi.org/10.1007/ s00449-010-0472-0. PMid:20963445.

Temeyer KB, Pruett JH, Olafson PU. Baculovirus expression, biochemical characterization and organophosphate sensitivity of rBmAChE1, rBmAChE2, and rBmAChE3 of Rhipicephalus (Boophilus) microplus. Vet Parasitol 2010; 172(1-2): 114-121. http://dx.doi. org/10.1016/j.vetpar.2010.04.016. PMid:20451328.

TRIPOS Associates. SYBYL-X 2.1.1: molecular modeling software packages, version 2.1.1. St. Louis; 2013.

UniProt [online]. 2019 [cited 2019 Oct 25]. Available from: www.uniprot.org/uniprot/062563

Vinutha B, Prashanth D, Salma K, Sreeja SL, Pratiti D, Padmaja R, et al. Screening of selected Indian medicinal plants for acetylcholinesterase inhibitory activity. J Ethnopharmacol 2007; 109(2): 359-363. http://dx.doi.org/10.1016/j.jep.2006.06.014. PMid:16950584.

Wang J, Cieplak P, Kollman PA. How well does a restrained electrostatic potential (RESP) model perform in calculating conformational energies of organic and biological molecules? J Comput Chem 2000; 21(12): 1049-1074. http://dx.doi. org/10.1002/1096-987X(200009)21:12<1049::AID-JCC3>3.0.CO;2-F.

Webb B, Sali A. Comparative protein structure modeling using MODELLER. Curr Protoc Bioinformatics 2016; 54(1): 5.6.1-5.6, 37. http://dx.doi.org/10.1002/cpbi.3. 
Williams SP, Kuyper LF, Pearce KH. Recent applications of protein crystallography and structure-guided drug design. Curr Opin Chem Biol 2005; 9(4): 371-380. http://dx.doi.org/10.1016/j.cbpa.2005.06.007. PMid:16006182.

Wright FC, Ahrens EH. Cholinesterase insensitivity: a mechanism of resistance in mexican strains of Boophilus microplus (Acari: Ixodidae) against coumaphos. J Med Entomo/ 1988; 25(4): 234-239. http://dx.doi.org/10.1093/jmedent/25.4.234. PMid:3404542.

Yadav R, Tikar SN, Sharma AK, Tyagi V, Sukumaran D, Jain AK, et al. Screening of some weeds for larvicidal activity against Aedes albopictus, a vector of dengue and chikungunya. J Vector Borne Dis 2015; 52(1): 88-94. PMid:25815872.

Zhou X, Xia Y. Cloning of an acetylcholinesterase gene in Locusta migratoria manilensis related to organophosphate insecticide resistance. Pestic Biochem Physiol 2009; 93(2): 77-84. http://dx.doi.org/10.1016/j.pestbp.2008.11.007. 


\section{Supplementary Material}

Supplementary material accompanies this paper.

Figure A.1 - Sequence alignment between diverse cholinesterase domains: RmAChE 1 (Target protein), HsAChE (Template, PDB ID: 4EY7) and TCAChE (Template, PDB ID: 2WFZ). The identical residues were highlighted in black and residues with similarity greater than 70\%, according to the BLOSUM 62 matrix, were highlighted in gray.

Figure B.1 - Comparison of Donepezil conformations at docking studies (black) and crystallographic structure (PDB ID: 4EY7, gray) at HsAChE site.

Figure C.1 - Stereochemical evaluation (Ramachandram plot) of the templates. Left - HsAChE (PDB ID: 4EY7) and right - TCAChE (PDB ID: 2WFZ).

This material is available as part of the online article from http://www.scielo.br/RBPV 